\title{
Avaliação do efeito do Risedronato Sódico na consolidação de fraturas: estudo experimental em ratos
}

The evaluation of the Sodic Risedronate effect in the fractures consolidation: experimental study with rats

\author{
Luiz Antonio Alcântara de Oliveira"; Roberto Guarniero 2; Consuelo Junqueira Rodrigues²; \\ Paulo José de Santana 1 ; Marco Antonio Batista ${ }^{3}$
}

\begin{abstract}
RESUMO
Realizou-se um estudo experimental com 40 ratos da raça Lewis visando-se avaliar a influência do risedronato sódico na consolidação de fraturas em animais submetidos à dieta aprotéica e dieta protéica, divididos aleatoriamente em quatro grupos, com 10 animais em cada grupo, assim constituídos: grupo I, com dieta protéica, sem risedronato (grupo controle); grupo II, dieta protéica, com risedronato; grupo III, dieta aprotéica, sem risedrionato; grupo IV, dieta aprotéica, com risedronato. Os ratos foram submetidos a fraturas semelhantes, no $15^{\circ}$ dia e à eutanásia no $43^{\circ}$ dia do experimento. As variáveis analisadas incluíram a evolução ponderal, avaliação radiográfica, densitometria óssea, avaliação histomorfométrica do calo ósseo, dosagens sanguíneas de cálcio, fósforo, fosfatase alcalina, proteínas totais, albumina e osteocalcina. Concluiu-se que o risedronato exerceu influência positiva no processo de consolidação de fraturas em ratos nutridos e desnutridos, e aumentou a densidade mineral óssea. O risedronato ocasionou a formação de tecido ósseo maduro de melhor qualidade e morfologia.
\end{abstract}

Descritores: Desnutrição protéica; Risedronato; Consolidação de fraturas; Ratos.

\section{INTRODUÇÃO}

A consolidação das fraturas é uma resposta especializada do organismo em que a regeneração do osso leva à restauração da integridade do esqueleto. Embora a maioria das fraturas consolide sem problemas, fatores como a desnutrição protéica, presente em nosso meio, podem interferir negativamente na consolidação de fraturas ${ }^{(9)}$.

Não há no arsenal farmacêutico um medicamento que acelere a consolidação das fraturas, apesar dos estudos que vêm sendo realizados no sentido de se buscar esse resultado ${ }^{(3,12)}$. Diante disso, empregou-se o risedronato sódico, um bisfosfonato formador de massa óssea, com o intuito de se observar a sua eficácia na consolidação das fraturas, através de um estudo experimental em ratos nutridos e desnutridos.

Analisou-se, através de análise estatística, o comportamento bioquímico do cálcio, fósforo e fosfatase alcalina, além das proteínas totais e albumina, e do marcador bioquímico da formação óssea, a osteocalcina. Foram também analisados estatisticamente os dados obtidos através de avaliações ponderal, radiográfica, densitométrica, histológica e histomorfométrica.

O objetivo deste trabalho é avaliar a influência do risedronato sódico, experimentalmente, no processo de consolidação de fraturas em ratos machos adultos, nutridos e subnutridos, nos quais foram provocadas fraturas nas tíbias direitas.

Este trabalho foi aprovado pelo Comitê de Ética em Pesquisa da Universidade Estadual de Londrina, Pr, em Parecer BIO 033/00 e pela Comissão de Ética para Análise de Projetos de Pesquisa do Hospital das Clínicas da Universidade de São Paulo sob o protocolo n 669/00.

Trabalho realizado no Instituto de Ortopedia e Traumatologia do Hospital das Clínicas da Faculdade de Medicina da universidade de São Paulo (FMUSP) e na Faculdade de Medicina da Universidade Estadual de Londrina (FMUEL)

\section{1 - Professor Adjunto Doutor da FMUEL}

2 - Professor Livre-Docente da FMUSP

3 - Professor Assistente da FMUEL

Endereço para correspondência: Rua José Evanildo Clóvis de Souza, 180, Jardim Monte Belo - Londrina, Paraná. CEP 86041-590

Telefones: (43) 3342-7993; 9991-4312 email:

alcantar@sercomtel.com.br

Trabalho recebido em 14/04/03. Aprovado em 06/04/04

\section{SUMMARY}

A experimental study with 40 rats of the Lewis type was done focusing the influence of sodic risedronate on fractures consolidation in the animals. They were submitted to a protein nutrition diet to a non-protein one, divided randomly in four groups, having 10 animals in each group. Like this: group 1, with a protein nutrition diet, without risedronate (control group); group II, protein nutrition diet $t$ with risedronate, group III, non-protein diet, without risedronate; group $\mathrm{N}$, non-protein diet with risedronate. The rats were submitted to similar fractures, on the $15^{\circ}$ day and to the euthanasia on the $43^{\circ}$ of the experiment. The variability analyzed included the ponderous evaluation, radiographic evaluation, the bone densitometry, histomorphometric bone callus evaluation, blood dosage of calcium, phosphorus, alkaline phosphatase, total proteins, albumin and osteocalcin. It was found out the risedronate had positive influence on the fractures consolidation process in nourished rats and malnourished rats and the mineral bone density increased. The risedronate caused the formation of the best nutrition and morphology of the ripen bone tissue.

Key words: Protein malnutrition; Risedronate; Fracture healing; Rats.

\section{INTRODUCTION}

The fractures consolidation is an organism specialized response where the regeneration of the bone leads to the restoration and integrity of the skeleton. Although many of the fractures consolidate without problems, some factors such as, protein malnutrition, can interfere negatively in the fractures consolidation ${ }^{(9)}$.

There is not a drug in the pharmaceutical medicaments which helps in the fast fracture consolidation. Even with studies that have been done in order to find a result ${ }^{(3,12)}$. Therefore; the sodic risedronate, a biphosphanates a bone body builder were used, wanting to observe its effectiveness in fractures consolidation, by the experimental study in nourished and non-nourished rats.

With the statistics analyses, the biochemical behaviour of the calcium, phosphorus and alkaline phosphatase, furthermore the total proteins and albumin, and the biochemical marker of the bone formation, the osteocalcin were analyzed. The obtained data by ponderate, radiography, densitometry, histological and histhomorphometrical evaluations were also analyzed.

The purpose of this work is to evaluate the sodic residronate influence, experimentally, in the fractures process consolidation in adult male rats, nourished or non-nourished, in which were done the right tibial fractures.

This work was approved by the Ethical committee of Research at the Clinicas Hospital in São Paulo University under the protocol $669 / 00$.

Work performed at the Orthopedics and Traumatology Institute of Clinicas Hospital of the Medicine School of the State of São Paulo (FMUSP) and in the Medicine State School in Londrina City (FMUEL).

1 - Associate Phd Professor at FMUEL

2 - Full Professor at FMUEL

3 - Assistant Professor at FMUEL

Adress: Rua José Evanildo Clóvis de Souza, 180, Jardim Monte Belo - Londrina, Paraná. CEP 86041-590 Telefones: (43) 3342-7993; 9991-4312 email: alcantar@sercomtel.com.br 


\section{MATERIAL E MÉTODO}

Foram utilizados 40 ratos de laboratório de linhagem Lewis, machos, adultos, isogênicos, com peso inicial variando entre 250 e 342 gramas.

Os animais foram divididos aleatoriamente em quatro grupos com dez animais em cada grupo, assim distribuídos: grupo I, com dieta protéica, sem o risedronato (grupo controle); grupo II, com dieta protéica, com risedronato; grupo III, com dieta aprotéica, sem risedronato; grupo IV, com dieta aprotéica, com risedronato, sendo mantidos em gaiolas, contendo cinco animais em cada uma, feitas de polietileno opaco, e fechadas com tampa de aço inoxidável em forma de grade, forradas com sepilho, e higienizadas três vezes por semana. No recinto onde os animais permaneciam, o período de luz foi de 12 horas, com temperatura, umidade e nível de ruído mantidos estáveis.

A dieta aprotéica, fornecida aos animais dos grupos III e IV, é padronizada e utilizada para desnutrição experimental em animais de laboratório.

Para a análise bioquímica, foram realizadas coletas de sangue através de punção cardíaca nos dias $1^{\circ}, 15^{\circ}$ e $43^{\circ}$ do experimento.

No $15^{\circ}$ dia, os ratos foram submetidos a fratura fechada do terço médio das tíbias direitas, realizadas manualmente por flexão forçada, procurando-se obter similaridade quanto ao traço, localização e mobilização do periósteo, estando os animais sob anestesia, através de injeção intraperitoneal de solução composta de cetamina na dose de $40 \mathrm{mg} / \mathrm{kg}$ e de xilazina na dose de $5 \mathrm{mg} / \mathrm{kg}^{(7,14)}$ de peso corporal diluídos em $1 \mathrm{ml}$ de solução salina. Após a realização das fraturas, os animais dos grupos II e IV passaram a receber dose diária de $1 \mathrm{mg} /$ $\mathrm{kg} /$ dia de risedronato sódico, através de gavagem com cateter de polietileno especialmente adaptado, medindo $5 \mathrm{~cm}$ de comprimento e $1 \mathrm{~mm}$ de diâmetro, sendo a solução preparada imediatamente antes de cada administração oral. A contenção do animal foi feita por técnico habilitado, e, afastando-se a mandíbula com espátula, administrou-se o medicamento aos grupos II e IV, sem necessidade de anestesia. A administração da solução de risedronato sódico foi efetuada em dose única diária, após a fratura, durante 28 dias.

A eutanásia dos animais ocorreu 28 dias após a realização das fraturas, no $43^{\circ}$ dia do experimento, atendendo-se a um protocolo de administração de dose letal obtida com anestesia injetável intraperitoneal de barbitúrico após a indução anestésica com halotano, finalizando com dose letal de cloreto de potássio. Após esse procedimento, realizou-se a pesagem e a desarticulação coxo-femoral direita dos animais para estudo do calo ósseo.

A avaliação do material de estudo foi feita de acordo com a evolução ponderal dos animais e das dosagens séricas do cálcio, fósforo, fosfatase alcalina, proteínas totais, albumina e osteocalcina no $1^{\circ}, 15^{\circ}$ e $43^{\circ}$ dias, e do estudo radiográfico, planimetria, densitometria, histologia e histomorfometria do calo ósseo no final do estudo.

Para o estudo estatístico, utilizou-se a técnica de análise de variância para o delineamento inteiramente casualizado, e mascaramento do tipo duplo-cego, em esquema fatorial de tratamento, com desdobramento dos graus de liberdade do efeito da interação entre a dieta e a medicação. Os dados obtidos foram analisados em nível de significância de $5 \%$, ou seja, os testes foram considerados significativos quando $p<0,05$.

\section{RESULTADOS}

A seguir, as tabelas com as médias e os desvios-padrões das variáveis mensuradas e sua respectiva análise de variância.

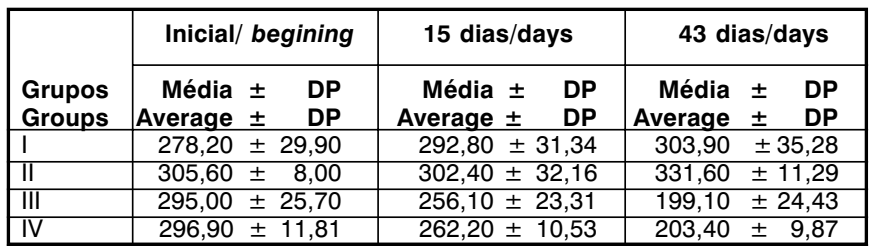

Tabela1 - Variação do peso dos animais, em gramas, nos diferentes grupos

Table 1 - Variation in grams of the animals' weight, in the different groups

\section{MATERIAL AND METHOD}

40 rats of the Lewis type, male, adult, isogenic, with the ideal weight ranging from 250 to 342 grams were used. The animals were divided randomly into four groups with 10 animals in each group, distributed as the following: group 1 with protein diet, without risedronate (control group); group II, with protein diet, with disedronate; group III, with protein diet, without risedronate; group $I$, with non-protein diet, with disedronate, kept in cages, with five animals in each of them, made of opaque polyethylene and close with a stainless lid in grade shape, covered with sawdust and cleaned three times a week. In the cages where the animals were kept, the light period was of twelve hours, with temperature, humidity and noise level remaining stable

The non-protein diet, given to groups III and IV, is standardized and used to the malnutrition experimental in laboratory animals.

To the biochemical analyses, blood collection were done with cardiac puncture on the $1^{\circ}, 15^{\circ}$ and $43^{\circ}$ day of the experiment.

On the $15^{\circ}$ day, the rats were submitted to a close fracture of the median third of the right tibias, done manually by forced flexion, trying to have similarity to the local traced and the peristoneous mobilization, having the animals under anesthetics, by intraperiosteal injection of a cetamine solution of $40 \mathrm{mg} / \mathrm{kg}$ and xilasine of a dosage of $5 \mathrm{mg} / \mathrm{kg}^{(7,14)}$ of body weight dissolved in $1 \mathrm{ml}$ of saline solution. After doing the fractures, the animals of group II and IV started having daily doses of $1 \mathrm{mg} / \mathrm{kg} /$ day of sodic risedronate, by the gavage using a catheter of polyethylene especially adapted, measuring $5 \mathrm{~cm}$ length and $1 \mathrm{~nm}$ diameter, preparing the solution immediately before each oral administration. The contention of the animal was done by a capable technician, and, separating the jaw with a spatula, administrated the drug to groups I/ and N, with no anesthetics. The administration of the sodic Risedronate was done with an only daily dose, after the fracture for 28 days.

The euthanasia of the animals occurred 28 days after the fractures, on the $43^{\circ}$ of the experiment, considering a protocol of administration of the lethal dose with intraperitoneal of barbituric injectable anesthetics after anesthesia induction with halothane, finishing with lethal dose of chloride of potassium After this procedure, the heaviness and the disarticulation of the right femoral thigh of the animals to the bone callus study.

The evaluation of the studied material was done according with the ponderous evolution of the animals and serial doses of calcium, phosphorus, alkaline phosphatase, total proteins, albumin and osteocalcin $1^{\circ}, 15^{\circ}$ and $43^{\circ}$ days, and the radiographic study, planimetry, densitometry, histology and histomorphometry of the bone callus at the end of the study.

To the statistics studies, the variance analyses technique was used in order to the outlining plan entirely casual, and mascarating the double-blind type, in the factorial scheme of the treatment, with the unbent of the liberty degrees of the effect of interaction between the diet and the medication. The obtained data were analyzed in significance of $5 \%$, that is, the tests were significantly considered when $p<0,005$.

\section{RESULTS}

Next, the tables with the averages and the standard variable factor measured and its respective variance analyses.

\begin{tabular}{|l|r|r|}
\hline $\begin{array}{l}\text { Causas de variação } \\
\text { Variance causes }\end{array}$ & $\begin{array}{c}\boldsymbol{p} \text { aos 15 dias } \\
\boldsymbol{p} \text { at 15 days }\end{array}$ & $\begin{array}{r}\boldsymbol{p} \text { aos 43 dias } \\
\boldsymbol{p} \text { at 43 days }\end{array}$ \\
\hline $\begin{array}{l}\text { Dieta } \\
\text { Diet }\end{array}$ & $<0,0001$ & $<0,0001$ \\
\hline $\begin{array}{l}\text { Risedronato na dieta protéica } \\
\text { Risedronate in the protein diet }\end{array}$ & 0,4116 & 0,0099 \\
\hline $\begin{array}{l}\text { Risedronato na dieta aprotéica } \\
\text { Risedronate in the non-protein diet }\end{array}$ & 0,6008 & 0,6748 \\
\hline
\end{tabular}

Tabela 2 - Valor de $p$ da análise de variância do efeito da interação entre dieta e medicação em relação ao peso dos animais

Table 2 - Value of $p$ of the variance analyzed effect of the interaction between the diet and medication related to the animal's weight 


\begin{tabular}{|l|rlc|}
\hline $\begin{array}{l}\text { Grupos } \\
\text { Groups }\end{array}$ & Média & \pm & Dp \\
\hline I & 124,80 & \pm & 25,21 \\
\hline II & 115,90 & \pm & 29,35 \\
\hline III & 61,30 & \pm & 24,73 \\
\hline IV & 62,00 & \pm & 19,96 \\
\hline
\end{tabular}

Tabela 3 - Variação da área planimétrica do calo ósseo, em $\mathrm{mm}^{2}$, aos 43 dias

Table 3 - Variation of the planymetric area of the bone callus in $\mathrm{mm}^{2}, 43$ days

\begin{tabular}{|lr|}
\hline Causas de variação/Variance causes & $\boldsymbol{p}^{\text {(a) }}$ \\
\hline Dieta/Diet & $<0,0001$ \\
\hline Risedronato na dieta protéica/Risedronate in the protein diet & 0,6229 \\
\hline Risedronato na dieta aprotéica/Risedronate in the non-protein diet & 0,9308 \\
\hline
\end{tabular}

(a)Transformação/Transformation $\log _{10}(\mathrm{X})$

Tabela 4 - Valor de $p$ da análise de variância do efeito da interação entre dieta e medicação em relação à área planimétrica do calo ósseo aos 43 dias

Table 4 - Value of $p$ of the variance effect of the interaction between the medication in relation of the planymetric area of the bone callus in the 43 days

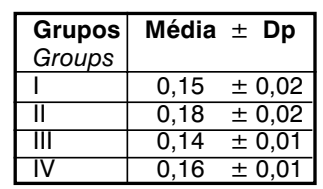

Tabela 5 - Variação da densidade mineral do calo ósseo, em $\mathrm{g} / \mathrm{cm}^{2}$, aos 43 dias

Table 5 - Mineral density variance of the bone callus, in $\mathrm{g} / \mathrm{cm}^{2}$, in the 43 days

\begin{tabular}{|lr|}
\hline Causas de variação / Variance causes & $\boldsymbol{p}$ \\
\hline Dieta/Diet & 0,1247 \\
\hline Risedronato na dieta protéica/Risedronate in the protein diet & 0,0025 \\
\hline Risedronato na dieta aprotéica/Risedronate in the non-protein diet & 0,0282 \\
\hline
\end{tabular}

Tabela 6 - Valor de $p$ da análise de variância do efeito da interação entre dieta e medicação em relação à análise densitométrica do calo ósseo aos 43 dias

Table 6 - Value of $p$ of the variance effect of the interaction between the medications in relation of densitometry analyses of the bone callus in the 43 days

\begin{tabular}{|l|c|c|c|}
\hline $\begin{array}{l}\text { Causas de variação } \\
\text { Variance causes }\end{array}$ & $\begin{array}{c}\boldsymbol{p}^{(\text {a) }} \\
\text { FIBROSE } \\
\text { Fibrose }\end{array}$ & $\begin{array}{c}p^{(a)} \\
\text { CARTILAGEM } \\
\text { Cartilage }\end{array}$ & $\begin{array}{c}p^{\text {(a) }} \\
\text { OSSO } \\
\text { Bone }\end{array}$ \\
\hline Dieta/Diet & 0,4138 & 0,0003 & 0,5589 \\
\hline $\begin{array}{l}\text { Risedronato na dieta protéica } \\
\text { Risedronate in the protein diet }\end{array}$ & 0,6916 & 0,3069 & 0,9262 \\
\hline $\begin{array}{l}\text { Risedronato na dieta aprotéica } \\
\text { Risedronate in the non-protein diet }\end{array}$ & 0,7302 & 0,0266 & 0,5931 \\
\hline
\end{tabular}

(a) Transformação $\log _{10}(\mathrm{X})$

Tabela 8 - Valor de $p$ da análise de variância do efeito da interação entre dieta e medicação em relação à histomorfometria do calo ósseo aos 43 dias

Table 8 - Value of $p$ of the variance effect of the interaction between the medications in relation of histomorphometry of the bone callus in the 43 days

\begin{tabular}{|l|r|r|}
\hline $\begin{array}{l}\text { Causas de variação } \\
\text { Variance causes }\end{array}$ & $\begin{array}{l}\boldsymbol{p} \text { 15 dias } \\
\mathbf{p} 15 \text { days }\end{array}$ & $\begin{array}{l}\text { p 43 dias } \\
\mathbf{p} 43 \text { days }\end{array}$ \\
\hline Dieta/Diet & $<0,0001$ & $<0,0001$ \\
\hline $\begin{array}{l}\text { Risedronato na dieta protéica } \\
\text { Risedronate in the protein diet }\end{array}$ & 0,0556 & $<0,0001$ \\
\hline $\begin{array}{l}\text { Risedronato na dieta aprotéica } \\
\text { Risedronate in the non-protein diet }\end{array}$ & 0,3935 & 0,0491 \\
\hline
\end{tabular}

Tabela 10 - Valor de $p$ da análise de variância do efeito da interação entre dieta e medicação em relação à dosagem sérica de cálcio dos animais aos 15 e 43 dias

Table 10 - Value of $p$ of the variance effect in the interaction between the medication in relation of the serial calcium dosage of animals on the 15 and 43 days

\begin{tabular}{|l|c|c|}
\hline $\begin{array}{l}\text { Causas de variação } \\
\text { Variance causes }\end{array}$ & $\begin{array}{l}\boldsymbol{p} \mathbf{1 5} \text { dias } \\
\boldsymbol{p} \mathbf{1 5} \text { days }\end{array}$ & $\begin{array}{c}\boldsymbol{p} \mathbf{4 3} \text { dias } \\
\boldsymbol{p} \mathbf{4 3} \text { days }\end{array}$ \\
\hline Dieta/Diet & 0,0002 & $<0,0001$ \\
\hline $\begin{array}{l}\text { Risedronato na dieta protéica } \\
\text { Risedronate in the protein diet }\end{array}$ & 0,2664 & 0,0883 \\
\hline $\begin{array}{l}\text { Risedronato na dieta aprotéica } \\
\text { Risedronate in the non-protein diet }\end{array}$ & 0,5429 & 0,4533 \\
\hline
\end{tabular}

Tabela 12 - Valor de $p$ da análise de variância do efeito da interação entre dieta e medicação em relação à dosagem sérica de fósforo dos animais aos 15 e 43 dias

Table 12 - Value of $p$ of the variance effect in the interaction between the medication in relation of the serial calcium dosage of animals on the 15 and 43 days

\begin{tabular}{|c|c|c|c|c|}
\hline \multirow[b]{2}{*}{ Grupos } & $\begin{array}{l}\% \text { Fibrose } \\
\% \text { Fibroses }\end{array}$ & \multicolumn{2}{|c|}{$\begin{array}{c}\% \text { Cartilagem } \\
\% \text { Cartilage }\end{array}$} & $\begin{array}{l}\text { \% Osso } \\
\% \text { Bone }\end{array}$ \\
\hline & Média \pm Dp & Média : & $\pm \quad D p$ & Média $\pm \quad D p$ \\
\hline $\mathrm{I}$ & $27,35 \pm 14,22$ & 34,73 & $\pm 14,08$ & $37,92 \pm 14,96$ \\
\hline Tा & $23,56 \pm 10,36$ & 40,38 & $\pm 11,19$ & $36,06 \pm 7,68$ \\
\hline III & $33,19 \pm 21,27$ & 18,86 & $\pm 10,20$ & $47,95 \pm 23,91$ \\
\hline IV & $29,75 \pm 7,49$ & 29,05 & 13,97 & $41,20 \pm 21,93$ \\
\hline
\end{tabular}

Tabela 7 - Variação histomorfométrica do calo ósseo nos diferentes grupos submetidos à eutanásia aos 43 dias

Table 7 - Histomorphometric variance of the bone callus in different groups submitted to euthanasia on the 43 days

\begin{tabular}{|c|c|c|c|c|c|c|c|c|}
\hline \multirow[b]{2}{*}{ Grupos } & \multicolumn{2}{|c|}{ Inicial/Begining } & \multicolumn{3}{|c|}{15 dias/days } & \multicolumn{3}{|c|}{43 dias/days } \\
\hline & Média \pm & Dp & Média & \pm & Dp & Média & \pm & Dp \\
\hline $\mathrm{T}$ & 9,62 & 0,80 & 9,66 & \pm & 0,99 & 8,82 & \pm & 0,54 \\
\hline$\pi$ & 9,54 & 0,83 & 9,09 & \pm & 0,64 & 7,62 & \pm & 0,50 \\
\hline III & 8,59 & 0,27 & 8,18 & \pm & 0,31 & 6,58 & \pm & 0,68 \\
\hline IV & $8,37 \pm$ & 0,43 & 7,93 & \pm & 0,41 & 6,74 & \pm & 0,38 \\
\hline
\end{tabular}

Tabela 9 - Variação do cálcio sérico, em $\mathrm{mg} / \mathrm{dl}$, dos animais nos diferentes grupos

Table 9 - Variation of serial calcium in $\mathrm{mg} / \mathrm{dl}$ of the animals in different groups

\begin{tabular}{|c|c|c|c|c|c|c|c|c|c|}
\hline \multirow[b]{2}{*}{ Grupos } & \multicolumn{3}{|c|}{ Inicial / Begining } & \multicolumn{3}{|c|}{15 dias/days } & \multicolumn{3}{|c|}{43 dias/days } \\
\hline & Média & \pm & Dp & Média & \pm & Dp & Média & \pm & Dp \\
\hline I & 4,34 & \pm & 0,30 & 4,26 & \pm & 0,30 & 4,22 & \pm & 0,32 \\
\hline II & 4,40 & \pm & 0,48 & 4,57 & \pm & 0,58 & 4,62 & \pm & 0,59 \\
\hline III & 4,47 & \pm & 0,73 & 3,68 & \pm & 0,77 & 3,04 & \pm & 0,61 \\
\hline IV & 4,11 & \pm & 0,80 & 3,51 & \pm & 0,75 & 2,86 & \pm & 0,48 \\
\hline
\end{tabular}

Tabela 11 - Variação do fósforo sérico, em $\mathrm{mg} / \mathrm{dl}$, dos animais nos diferentes grupos

Table 11 - Variation of the serial phosphorus, in $\mathrm{mg} / \mathrm{dl}$ of the animals in different groups

\begin{tabular}{|c|c|c|c|c|c|c|c|c|}
\hline \multirow[b]{2}{*}{ Grupos } & \multicolumn{2}{|c|}{ Inicial/Begining } & \multicolumn{3}{|c|}{15 dias/days } & \multicolumn{3}{|c|}{43 dias/days } \\
\hline & Média \pm & Dp & Média & \pm & $\mathrm{Dp}$ & Média & $I$ & Dp \\
\hline 1 & $261,10 \pm$ & 44,33 & 245,70 & \pm & 52,02 & 290,60 & \pm & 90,36 \\
\hline II & $262,90 \pm$ & 60,28 & 254,30 & \pm & 47,17 & 290,20 & \pm & 21,12 \\
\hline TII & $221,30 \pm$ & 54,06 & 214,10 & \pm & 49,40 & 199,60 & \pm & 60,09 \\
\hline IV & $175,00 \pm$ & 28,71 & 165,90 & \pm & 29,54 & 200,20 & \pm & 32,23 \\
\hline
\end{tabular}

Tabela 13 - Variação da fosfatase alcalina sérica, em ui/l, dos animais nos diferentes grupos

Table 13 - Variation of serial alkaline phosphatase, in ui/l, of the animals in different groups 


\begin{tabular}{|l|c|c|}
\hline $\begin{array}{l}\text { Causas de variação } \\
\text { Variance causes }\end{array}$ & $\begin{array}{r}\boldsymbol{p}^{(\mathrm{a})} \mathbf{1 5} \text { dias } \\
\boldsymbol{p} \mathbf{1 5} \text { days }\end{array}$ & $\begin{array}{c}\boldsymbol{p}^{(\mathrm{a})} \mathbf{4 3} \text { dias } \\
\mathbf{p} \mathbf{4 3} \text { days }\end{array}$ \\
\hline Dieta/Diet & 0,0002 & $<0,0001$ \\
\hline $\begin{array}{l}\text { Risedronato na dieta protéica } \\
\text { Risedronate in the protein diet }\end{array}$ & 0,6919 & 0,7531 \\
\hline $\begin{array}{l}\text { Risedronato na dieta aprotéica } \\
\text { Risedronate in the non-protein diet }\end{array}$ & 0,0134 & 0,7638 \\
\hline
\end{tabular}

(a) Transformação $\log _{10}(X)$

Tabela 14 - Valor de $p$ da análise de variância do efeito da interação entre dieta e medicação em relação à dosagem sérica da fosfatase alcalina dos animais aos 15 e 43 dias

Table 14 - Value of $p$ of the variance effect in the interaction between the diet and medication in relation of the serial alkaline phosphatase dosage of animals on the 15 and 43 days

\begin{tabular}{|l|c|c|}
\hline $\begin{array}{l}\text { Causas de variação } \\
\text { Variance causes }\end{array}$ & $\begin{array}{c}p 15 \text { dias } \\
\boldsymbol{p} \text { 15 days }\end{array}$ & $\begin{array}{c}p 43 \text { dias } \\
\boldsymbol{p} \text { 43 days }\end{array}$ \\
\hline Dieta/Diet & $<0,0001$ & $<0,0001$ \\
\hline $\begin{array}{l}\text { Risedronato na dieta protéica } \\
\text { Risedronate in the protein diet }\end{array}$ & 0,2627 & 0,9058 \\
\hline $\begin{array}{l}\text { Risedronato na dieta aprotéica } \\
\text { Risedronate in the non-protein diet }\end{array}$ & 0,5843 & 0,3346 \\
\hline
\end{tabular}

Tabela 16 - Valor de $p$ da análise de variância do efeito da interação entre dieta e medicação em relação à dosagem sérica das proteínas totais dos animais aos 15 e 43 dias

Table 16 - Value of $p$ of the variance effect in the interaction between the diet and medication in relation of the serial total protein dosage of animals on the 15 and 43 days

\begin{tabular}{|l|c|r|}
\hline $\begin{array}{l}\text { Causas de variação } \\
\text { Variance causes }\end{array}$ & $\begin{array}{c}\text { p15 dias } \\
\mathbf{p} \mathbf{1 5} \text { days }\end{array}$ & $\begin{array}{c}\text { p43 dias } \\
\boldsymbol{p} \text { 43 days }\end{array}$ \\
\hline Dieta/Diet & 0,0069 & 0,0153 \\
\hline $\begin{array}{l}\text { Risedronato na dieta protéica } \\
\text { Risedronate in the protein diet }\end{array}$ & 0,1652 & 0,0297 \\
\hline $\begin{array}{l}\text { Risedronato na dieta aprotéica } \\
\text { Risedronate in the non-protein diet }\end{array}$ & 0,3721 & 0,5417 \\
\hline
\end{tabular}

Tabela 18 - Valor de $p$ da análise de variância do efeito da interação entre dieta e medicação em relação à dosagem sérica de albumina dos animais aos 15 e 43 dias

Table 18 - Value of $p$ of the variance effect in the interaction between the diet and medication in relation of the serial albumin dosage of animals on the 15 and 43 days

\begin{tabular}{|c|c|c|c|c|c|c|c|c|c|}
\hline \multirow[b]{2}{*}{ Grupos } & \multicolumn{3}{|c|}{ Inicial/Begining } & \multicolumn{3}{|c|}{15 dias/days } & \multicolumn{3}{|c|}{43 dias/days } \\
\hline & Média & \pm & Dp & Média & \pm & Dp & Média & \pm & Dp \\
\hline I & 7,05 & \pm & 0,63 & 7,08 & \pm & 0,61 & 6,97 & \pm & 0,78 \\
\hline II & 7,26 & \pm & 0,32 & 7,28 & \pm & 0,34 & 6,94 & \pm & 0,33 \\
\hline III & 7,09 & \pm & 0,31 & 6,45 & \pm & 0,31 & 5,52 & \pm & 0,18 \\
\hline IV & 7,16 & \pm & 0,22 & 6,55 & \pm & 0,24 & 5,72 & \pm & 0,24 \\
\hline
\end{tabular}

Tabela 15 - Variação das proteínas totais séricas, em $\mathrm{g} / \mathrm{dl}$, dos animais nos diferentes grupos

Table 15 - Variation of serial total proteins, in $\mathrm{g} / \mathrm{dl}$. of the animals in different groups

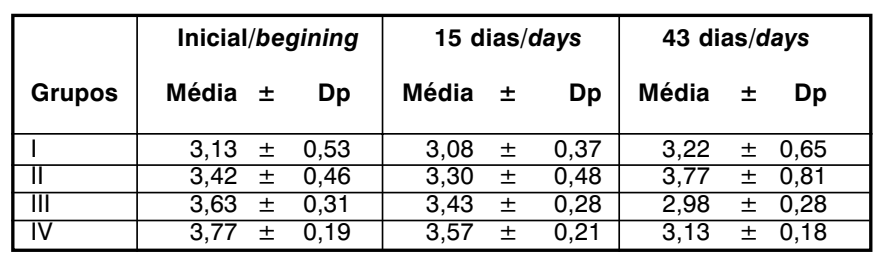

Tabela 17 - Variação da albumina sérica, em $\mathrm{mg} / \mathrm{dl}$, dos animais nos diferentes grupos

Table 17 - Variation of serial albumin , in $\mathrm{mg} / \mathrm{dl}$. of the animals in different groups

\begin{tabular}{|c|c|c|c|c|c|c|c|c|c|}
\hline \multirow[b]{2}{*}{ Grupos } & \multicolumn{3}{|c|}{ Inicial/begining } & \multicolumn{3}{|c|}{15 dias/days } & \multicolumn{3}{|c|}{43 dias/days } \\
\hline & Média & \pm & DP & Média & \pm & DP & Média & \pm & DP \\
\hline 1 & 13,20 & \pm & 1,68 & 12,21 & \pm & 1,63 & 15,02 & \pm & 3,86 \\
\hline II & 15,87 & \pm & 3,88 & 15,10 & \pm & 2,26 & 19,89 & \pm & 3,42 \\
\hline III & 15,41 & \pm & 2,23 & 16,02 & \pm & 2,79 & 22,33 & \pm & 5,71 \\
\hline IV & 15,94 & \pm & 3,32 & 16,42 & \pm & 1,90 & 5,01 & \pm & 3,23 \\
\hline
\end{tabular}

Tabela 19 - Variação da osteocalcina sérica, em $\mu \mathrm{g} / \mathrm{dl}$ dos animais nos diferentes grupos

Table 19 - Variation of serial osteocalcin, in $\mu \mathrm{g} / \mathrm{dl}$ of the animals in different groups

\section{DISCUSSÃO}

A avaliação clínica comparativa e sistemática da formação do calo ósseo em fraturas apresenta muitas dificuldades, pois há inúmeras diferenças individuais no que diz respeito à natureza e ao local da fratura, curso e duração da consolidação. Porém, particularmente difícil é estudar os métodos terapêuticos capazes de influenciar a formação do calo ósseo. Assim, é natural que se aborde esse problema experimentalmente, para podermos comparar de maneira homogênea o material, isto é, as mesmas condições quanto ao sexo, idade, peso dieta, natureza e localização da fratura. Além disso, em países em desenvolvimento como o Brasil, deve-se considerar o estado nutricional como fator influente na consolidação de fraturas, pois dele depende a restauração à integridade do esqueleto.

Neste experimento, o animal utilizado foi o rato, por ser o modelo mais prático e comum. As fraturas são de rápida consolidação, dispensando imobilização externa ou interna, e sem complicações im-

\begin{tabular}{|l|c|c|}
\hline Causas de variação & $\begin{array}{c}p \text { 15 dias } \\
\mathbf{p} \text { 15 days }\end{array}$ & $\begin{array}{c}\boldsymbol{p}^{(\mathrm{a})} \mathbf{4 3} \text { dias } \\
\mathbf{p} \text { 43 days }\end{array}$ \\
\hline Variance causes & 0,0007 & $<0,0001$ \\
\hline Dieta/Diet & 0,0055 & 0,0498 \\
Risedronato na dieta protéica & 0,6850 & 0,0024 \\
Risedronate in the protein diet & & \\
Risedronato na dieta aprotéica \\
Risedronate in the non-protein diet
\end{tabular}

Tabela 20 - Valor de $p$ da análise de variância do efeito da interação entre dieta e medicação em relação à dosagem sérica de osteocalcina dos animais aos 15 e 43 dias

Table 20 - Value of $p$ of the variance effect in the interaction between the diet and medication in relation of the serial osteokaline dosage of animals on the 15 and 43 days

\section{DISCUSSION}

The comparative and systematic clinical evaluation of the bone callus formation shows many difficulties, due to a lot of individual differences about the nature and the fracture place, the course and consolidation. However, it is particularly difficult the therapeutics methods studies to be able to influence the bone callus formation. Therefore, it is natural the approach of this experiment problem. Furthermore, in developing countries like Brazil, the nutrition must be considered as an important factor of the fractures consolidation, because it depends on it the skeleton integrity restoration.

In this experiment, the rat was the animal used, due to be a practical and common model. The fractures have fast consolidation, not need internal or external mobilization, and without important complications. The model also enables the blood collection to the Biochemistry studies. The bone alterations related 
portantes. O modelo também possibilita a coleta de sangue para a o estudo bioquímico. As alterações ósseas relacionadas à evolução do calo ósseo podem ser facilmente verificadas nesse modelo animal(10) O modelo também permite a avaliação da formação do calo ósseo em situações como a desnutrição ${ }^{(9)}$, ou da ação de substâncias como a calcitonina( ${ }^{(8)}$, alendronato sódico ${ }^{(12)}$, fluoreto de sódio ${ }^{(2)}$, complexo osseína-hidroxiapatita ${ }^{(3)}$

As fraturas foram obtidas por osteoclasia manual ${ }^{(13)}$, e mostraram similaridade satisfatória, com pequenas diferenças de localização, porém sem necessidade de se criar um dispositivo mecânico para a sua realização. A comparação de consolidação de fraturas experimentais exige similaridade, o que se procurou obter neste experimento. Os animais não foram imobilizados, tendo sido deixados livres para a deambulação, porque a imobilização, além de ser desnecessária, poderia criar possibilidade de interferência pela presença de material de síntese ${ }^{(8)}$

A via peritoneal, para a realização da anestesia, é a mais usada para roedores. Não houve complicações durante o ato anestésico, o que nos permite assegurar a eficácia desta conduta.

A dieta aprotéica para desnutrição experimental ${ }^{(11)}$ levou à desnutrição protéica, verificada na análise dos valores das proteínas totais $(p<0,0001)$ e da albumina $(p=0,0153)$. A desnutrição protéica assim obtida teve interferência direta na consolidação das fraturas, o que concorda com observações obtidas em outros estudos ${ }^{(8,9)}$

O medicamento utilizado neste experimento com o fim de se analisar sua possível influência como adjuvante na consolidação das fraturas, o risedronato sódico, é um piridinil bisfosfonato de terceira geração que, como outros bisfosfonatos, inibe a reabsorção óssea mediada pelos osteoclastos ${ }^{(5)}$.

A formação de uma ponte entre os fragmentos de um osso fraturado constitui o passo mais importante na sua consolidação; a quantidade de calo ósseo é a porção visível nas radiografias ${ }^{(1)}$. As fraturas experimentais nas tíbias de ratos atingem a fase de ossificação em torno da quarta semana de evolução, quando já demonstram evidências radiográficas de consolidação. Com base nesses dados, foi determinada a eutanásia dos animais 28 dias após a realização das fraturas, para a avaliação radiográfica, densitométrica e histológica do calo ósseo.

A desnutrição dos animais dos grupos III e IV foi evidenciada pela significante perda de peso $(p<0,0001)$, o que foi observado já no $15^{\circ}$ dia do experimento, ocasião em que foram realizadas as fraturas, persistindo a perda de peso até o final do experimento.

Para a avaliação planimétrica, foram feitas radiografias (Figuras 1 e 2) depois da desarticulação do joelho. Na avaliação radiográfica, a diferença entre os resultados médios dos calos ósseos foi estatisticamente significante $(\mathrm{p}<0,0001)$, havendo menor área de calo ósseo nos grupos que consumiram a dieta desprovida de proteínas, o que concorda com os achados de outros estudos ${ }^{(9)}$ que demonstraram haver calo mais abundante nas fraturas em ratos nutridos quando comparados aos subnutridos.

A análise densitométrica mostrou diferença estatisticamente significante quando houve a administração do risedronato. Os bisfosfonatos se aderem aos minerais do osso, agindo sobre os osteoclastos, têm alta seletividade de localização e retenção nos ossos, e podem aumentar a massa óssea ${ }^{(5)}$. Este fato vem também confirmar o mecanismo de ação do risedronato como inibidor da reabsorção óssea mediada pelos osteoclastos.

Comparando os grupos com dieta aprotéica com e sem risedronato, os estudos histológicos não apresentaram diferença significante quanto à quantidade de osso formado, porém observou-se que no grupo com dieta aprotéica com risedronato, havia mais tecido ósseo maduro, evidenciando calcificação ao exame anátomo-patológico, quando comparado ao grupo com dieta aprotéica sem o medicamento. Assim, qualitativamente, o risedronato contribuiu para a formação de tecido ósseo maduro, de melhor qualidade e morfologia, embora quantitativamente não tenha oferecido diferença significativa, ao exame histológico, nas amostras dos grupos submetidos às dietas protéica e aprotéica (Figuras 3-6). Essa diferença na qualidade do tecido ósseo foi também observada nos grupos com dieta protéica, comparando-se os grupos com e sem risedronato, o que constata que o risedronato melhora a arquitetura trabecular ${ }^{(6,12)}$.

$\mathrm{Na}$ avaliação dos componentes teciduais das diferentes amostras, ao se avaliar a porcentagem de tecido fibroso, e de osso neofor- to the bone callus evolution can be easily seen in these animals model/(10). The model also allows the evaluation of the bone callus formation in situations such as, malnutrition ${ }^{(9)}$, or the effect of the substances as calcitonin ${ }^{(8)}$, sodic alendronate ${ }^{(12)}$, sodium fluoride $^{(2)}$, bone ossific -hydroxyapathitis ${ }^{(3)}$

The fractures were obtained by manual osteoclasis ${ }^{(13)}$, and showed satisfactory similarities, with small local differences, however with no need for creating a mechanical device to do it. The comparison of experimental fractures consolidation demands similarity, and what was tried to be found in this experiment. The animals were not mobilized, letting them free for strolling, the mobilization, besides being unnecessary, could create the possibility of interference due to the presence of the synthesis material(8)

The peritoneal via, to the anesthetics, is the most used for rats. There were no complications during the anesthetics act, what allows us assure the effectiveness of this action.

The non-protein to the experimental malnutrition ${ }^{(11)}$ led to the protein malnutrition, checked in the values analyses of the total proteins $(p<0,0001)$ and the albumin $(p=0,0153)$, the protein malnutrition therefore obtained had direct interference in the fractures consolidation, which goes with obtained observations of other studies ${ }^{(8,9)}$

The medication used in this experiment in order to analyzed its possible influence as supporter in the fracture consolidation, the sodic risedronate, it is a third generation pyridine bisphosphonates, together with other bisphosphonates, inhibit the bone reabsorption mediated for the osteoclast ${ }^{(5)}$.

The formation of a bridge between the fragments of a fractured bone is the most important step in its consolidation; the quantity of bone callus is the most visible area in the radiographies $^{(1)}$. The experimental fractures in the tibias of rats reach the ossification phase around the fourth week evolution, when already has shown evidences in the consolidation radiographies. Based on these data, the euthanasia of the animals was determinated 28 days after the fractures action, to the radiography, densitometry and histoly evaluation of bone callus.

The malnutrition of the animals of group III and IV was proved because of the significant weight loss $(p<0,0001)$, what could have been seen on the $15^{\circ}$ of the experiment, when the fractures were done, the weight loss continuing until the end of the experiment.

To the planimetric evaluation were done radiographies (Figures 1 and 2) after the knee disarticulation. In the radiography evaluation, the difference between the average results of the bone callus was statistically significant $(p<0,0001)$, having smaller area of the bone callus in groups which consumed the diet without proteins, which is in accordance with what was found in other studies ${ }^{(9)}$ that showed to have more abundant callus number in fractures in nourished rats when compared to the nonnourished ones.

The densitometry analyses showed difference statistically significant when the administration of risedronate happened. The bisphosphonates adheres to the bone minerals, acting on the osteoclasts, has highly selective location and retention in the bones, and can increase the bone bosy ${ }^{(5)}$. This confirms the mechanism of action of the risedronate as an inhibitor of the bone reabsorption mediate by the osteoclasts.

Comparing the animals with non-protein diet with or without risedronate, the histological studies does not show significant difference to the quality of the bone formed, however it was observed the in the non-protein diet group with risedronate, there was more rape bone tissue, showing the calcification to the anatomic-pathologic exam, when compared to the non-protein diet group without medication. Thus, the risedronate contributed qualitatively with the rape bone tissue formation, best quality and morphology, although has not offered significant difference quantitatively to the histological exams in samples of groups submitted to protein and non-protein diet (Figures 3 and 6). This difference in the quality of the bone tissue was also observed in groups with protein diet, comparing them to the groups with or without risedronate, what shows the risedronate improves the trabecular architecture $^{(6,12)}$ 

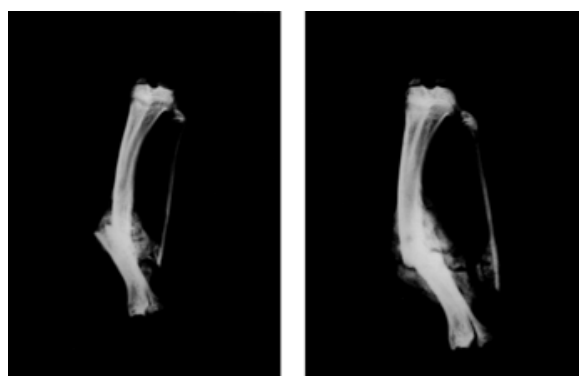

Figura 1 - Radiografias de patas traseiras de animais do grupo I (a) e II (b), mostrando fraturas consolidadas na transição do terço médio para distal da tíbia com grande calo ósseo.

Figure 1 - Radiographs of animals hide foot of group 1 (a) and II (b); showing consolidate fracture from the third medial transition to the distal tibia with a large bone callus.

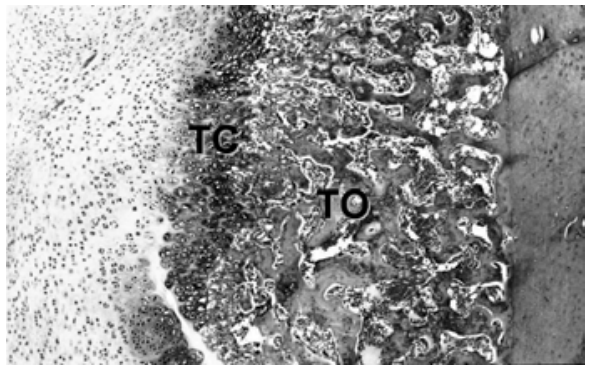

Figura 4 - Fotomicrografia do calo ósseo de animal do Grupo II, quatro semanas após a fratura. Observa-se o predomínio de tecido ósseo neoformado (TO), e tecido cartilaginoso (TC). (HE, 100X).

Figure 4 - Photomicrography of animals with bone callus of group II four weeks after the fracture. The predominance of the neoformation of bone tissue (BT) and cartilaginous tissue (CT) (HE; 100X)was observed

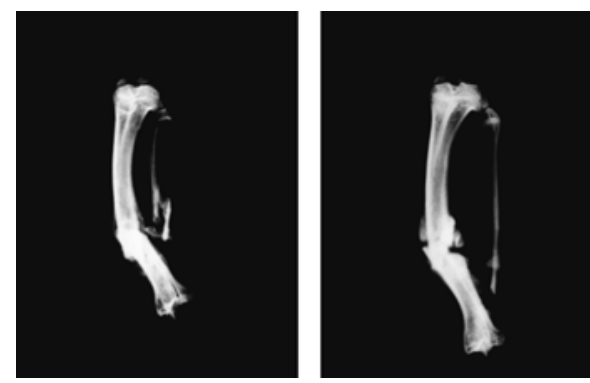

Figura 2 - Radiografias de patas traseiras de animais do grupo III (a) e IV (b), mostrando fraturas em consolidação na transição do terço médio para distal da tíbia com pequeno calo ósseo.

Figure 2 - radiographs of animals hide foot of group III (a) and IV(b); showing a process of consolidation of fractures from the medial third transition to the distal tibia with a small bone callus.

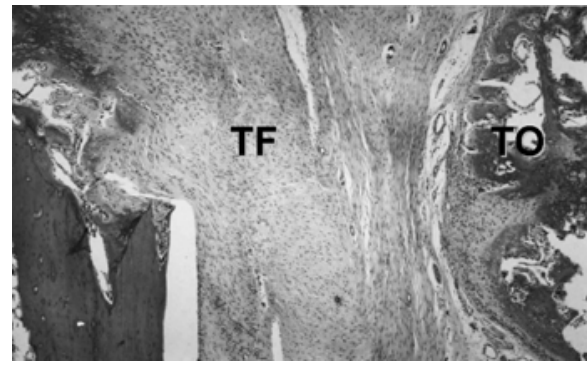

Figura 5 - Fotomicrografia do calo ósseo de animal do Grupo III, quatro semanas após a fratura. Observa-se o predomínio de tecido fibroso (TF), e a presença de tecido ósseo neoformado (TO) (HE, 100X).

Figure 5 - Photomicrography of the bone callus of Group III, four weeks after the fracture. The predominance of the fibroses tissue (FT) and the neo-formation of the bone tissue (BT) (HE, 100X) was observed.

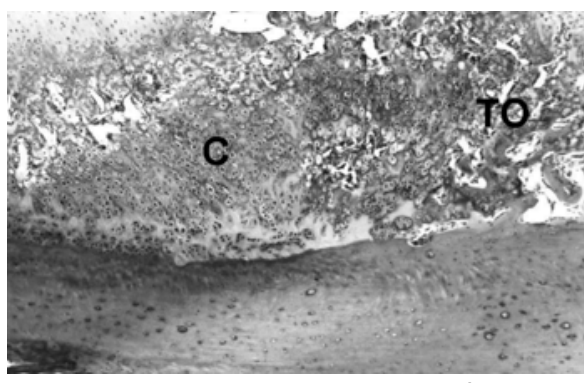

Figura 3 - Fotomicrografia do calo ósseo de animal do Grupo I, quatro semanas após a fratura. Observam-se células cartilaginosas

(C) em grande quantidade e tecido ósseo neoformado (TO) (HE, 100X).

Figure 3 - Photomicrography of the animal bone callus Group I four weeks after the fracture. A great amount of cartilaginous cells and the neoformation of the bone tissue were observed.

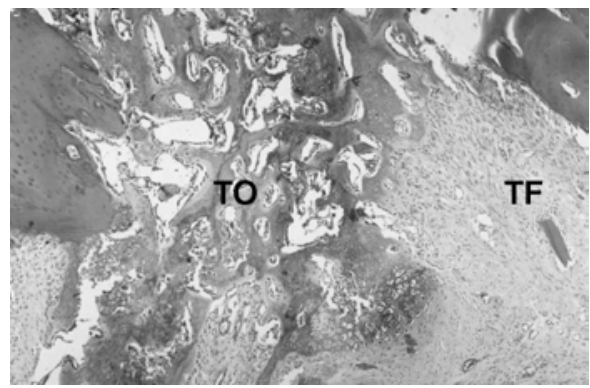

Figura 6 - Fotomicrografia do calo ósseo de animal do Grupo IV, quatro semanas após a fratura. Observa-se tecido ósseo neoformado (TO), e tecido fibroso (TF). Há, também, pequenos focos de cartilagem (C) (HE, 100X). Figure 6 - Photomicrography of the bone callus of an animal of Group IV, four weeks after the fracture, The neo-formation of the bone tissue (BT) and fibroses tissue (FT). There are also small focus of cartilage $(C)$ (HE, 100X). mado, verificou-se que não houve significância estatística nos grupos de diferentes dietas, com ou sem a administração do risedronato. Porém, quando avaliado o percentual de tecido cartilagíneo, verificou-se diferença estatisticamente significante $(p<0,05)$, com aumento do mesmo, quando o risedronato foi administrado ao grupo de dieta aprotéica. Isso é significativo por ser provável que a cartilagem evolua para ossificação endocondral. Contudo, não há garantia disso, visto que é possível a evolução para retardo de consolidação ou mesmo para pseudartrose.

$\mathrm{Na}$ avaliação laboratorial dos níveis de cálcio, observou-se diferença significativa nos níveis séricos do cálcio $(p<0,05)$ nos grupos que receberam o risedronato tanto de dieta aprotéica como o de dieta protéica, confirmando o efeito hipocalcemiante dos bisfosfonatos ${ }^{(5)}$

A análise dos níveis séricos da fosfatase alcalina revelou diferenca estatisticamente significante nos grupos com dietas diferentes, sendo diminuída nos grupos com dieta aprotéica, o que pode ser explicado pela desnutrição; porém, a adição do risedronato não causou diferença estatisticamente significante nos diferentes grupos.

A análise das variações dos níveis séricos das proteínas totais, possibilitou verificar que houve diferença estatisticamente significante quando analisada a dieta $(p<0,001)$, confirmando a desnutrição protéica. A adição do risedronato não causou diferença significativa nos grupos que receberam o medicamento.
In the evaluation of the tissues components of the different samples, when evaluating the percentage of the fibroses tissues, and the neo-formed bone, it was seen there was significative statistics in groups with different diets, with or without the risedronate administration. However, when evaluated the percentage of the cartilaginous tissue, the statistically significance difference $(p<0,05)$, with the increase of it, when the risedronate was administrated to the group of non-protein diet. This is significative for being likely the cartilage evolutes to the endochondral ossification. However, there is no guarantee of it, considering it is possible the evolution for the consolidation retard or even for the pseudartroses.

In the laboratorial evaluation of the level of calcium, a significative different was observed in the serial of calcium leve $(p<0,05)$ in the groups which receive risedronate in both the protein and non-protein diet, confirming the hipocalcemiant effect of the bisphosphonates ${ }^{(5)}$

The analyses of the level of the serial alkaline phosphates showed differences statistically significant in the groups with different diets, being smaller in groups with non-protein diet what can be explained with the malnutrition; however, the adding of risedronate did not cause difference statistically significant in different groups. 
Em relação à análise dos níveis séricos da albumina, houve diferença estatisticamente significante na análise das diferentes dietas. A presença do risedronato na dieta protéica foi estatisticamente significante, o que pode sugerir que esse medicamento talvez interfira no metabolismo dessa proteína, abrindo espaço para mais estudos desse assunto.

A osteocalcina, uma proteína de baixo peso molecular, sintetizada pelos osteoblastos, e específica para o tecido ósseo, tem seus níveis séricos aumentados na formação óssea ${ }^{(4)}$. Neste experimento, os níveis séricos desta proteína estiveram aumentados no grupo em que o risedronato foi administrado aos animais que consumiam a dieta aprotéica, apresentando diferença estatisticamente significante $(\mathrm{p}=0,0024)$ aos 43 dias. Apresentou, também, diferença estatisticamente significante $(p=0,0498)$ no grupo que recebeu dieta protéica. A osteocalcina é produzida e liberada pelos osteoblastos durante a formação óssea, e o aumento sérico deste marcador do metabolismo ósseo neste experimento, principalmente quando da administração do risedronato, demonstra uma elevação da atividade osteoblástica que traduz produção óssea, isto é, anabolismo.

O risedronato exerceu influência significativa em diversas variáveis, como na quantidade relativa de cartilagem, que é o sítio para a ossificação endocondral, presente no calo ósseo; na densitometria óssea; no marcador da formação óssea, a osteocalcina; sendo sua ação principalmente nos animais desnutridos. Isso pode ter uma aplicação clínica importante, principalmente em se tratando de pacientes que vierem a sofrer fraturas estando em situação de carência nutricional, como pacientes acamados por longo período, idosos, ou em outra situação de desvantagem, o que certamente nos desafia a novas pesquisas nessa área.

\section{CONCLUSÕES}

O risedronato sódico administrado por via oral na dose de $1 \mathrm{mg} /$ kg de peso corporal exerceu influência positiva no processo de consolidação de fraturas em ratos nutridos ou desnutridos.

O risedronato sódico apresentou significância estatística na avaliação da densidade mineral óssea nos ratos nutridos e desnutridos.

$\mathrm{Na}$ avaliação bioquímica, a osteocalcina demonstrou que o risedronato contribuiu positivamente para a formação óssea nos animais.
The analyses of the varieties of the serial levels of the total proteins, enable to observe the difference statistically significant when the analyzed diet $(p<0,001)$, confirming the protein malnutrition. The adding of risedronate did not cause significative difference in the groups which received the medication.

In relation of the analyses of the serial level of albumin, there was difference statistically significant, what suggests maybe this medication interferes in the metabolism of this protein, drawing to more discussion about this subject.

The osteocalcin, a protein of low molecular weight, synthesized by the osteoblasts, and specify to the bones study, has its seric level increased in the bone formation ${ }^{(4)}$. In this experiment, the serial levels of this protein were increased in the group where the risedronate was administrated to the animals that consumed the protein diet, showing difference statistically significant $(p=0,0024)$ in the 43 days. Also showed difference statistically significant $(p=0,0498)$ in the group which received protein diet. The osteocalcin is produced and liberate by the osteoblastos during the bone formation, and the serial increase of this bone metabolism marker in this experiment, mainly when the risedronate administration, shows a high osteoblastic activity which translate bone production, that is, anabolism.

The risedronate had significative influence in several variances, such as, relative amount of cartilage, that is the place to the enchondral ossification, present in the bone callus, in the bone densitometry; in the marker of the bone formation, the osteocalcin, being its action mainly in malnutrition of the animals. This can have an important clinical application, mainly when referring to patients who suffered from fractures being in situation of nutrition careless, as patients in bed for long time, elder, or in another situation of disadvantage, what certainly challenge the new researches in this area.

\section{CONCLUSIONS}

The sodic risedronate administrated by oral via in dose of 1 $\mathrm{mg} / \mathrm{kg}$ of body weight had positive influence in the fractures consolidation process in nourished or non-nourished rats.

The sodic risedronate showed signicant statistics in the evaluation of the bone mineral density of the nourished and nonnourished rats.

In the biochemical evaluation, the osteocalcin showed the disedronate contributed positively to the bone formation of the animals.

\section{REFRÊNCIAS BIBLIOGRÁFICAS}

1. Aro, H., Eerola, E., Aho, A. J.: Determination of callus quantity in 4-week-old fractures of the rat tibia. J. Orthop. Res. 3: 101-108, 1985

2. Batista, M. A.: Avaliação do efeito do fluoreto de sódio na consolidação das fraturas: estudo experimental em ratos. Londrina, 2000. 67 p. Dissertação (mestrado). Universidade Estadual de Londrina.

3. Campos, W. G.: Avaliação do efeito do complexo osseína-hidroxiapatita na consolidação das fraturas na desnutrição protéica: estudo experimental em ratos. Acta Ortop. Bras. 9: 21-25, 2001

4. Delmas, P. D.: Clinical use of biochemical markers of bone remodelling in osteoporosis. Bone 13: 17-21, 1992.

5. Fleisch, $\mathrm{H}$.: Mechanisms of action of the bisphosphonates. Medicina, Buenos Aires 57 (suppl) 1: 65-75, 1997

6. Goa, K. L., Balfour, J. A.: Risedronate. Drugs Aging: 13: 83-91, 1998.

7. Goss-Sampson, M. A., Kriss, A.: Effects of pentobarbital and ketamine-xylazine anaesthesia on somatosensory, brainstem auditory and peripheral sensory-motor responses in the rat. Laboratory animals: 25:360-66, 1991.

8. Guarniero, R., Barros, T. E. P., Zerbini, C. A. F., Rodrigues C. J. J., Pedrinelli Corsato, M., Reis, P. R.: Estudo da consolidação de fraturas na desnutrição protéica: trabalho experimental com o uso da calcitonina em ratos desnutri- dos. São Paulo, 1979. 45p. (Monografia) Departamento de Ortopedia e Traumatologia da Faculdade de Medicina da Universidade de São Paulo.

9. Guarniero, R., Barros Fo, T. E. P,; Tannuri, U., Rodrigues, C. J., Rossi J. D. M. B A.: Study of fracture healing in protein malnutrition. Rev. Paul. Med., 110: 6368, 1992.

10. Maeda, H., Kimmel, D. B., Lane, N., Raab, D.: The musculoskeletal response to immobilization and recovery. Bone 14: 153-159, 1993.

11. Modolin, M. L. A. Bevilacqua, R. G. Margarido, N. F. Lima-Gonçalves, E Cicatrização das feridas abertas na desnutrição com hipoproteinemia. Rev. Hosp. Clin. Fac. Med. S. Paulo 37: 275-278, 1982

12. Santana, P. J.: Estudo da consolidação de fraturas na desnutrição protéica: trabalho experimental com o uso de alendronato em ratos. São Paulo, 1999. 122p. Tese (doutorado). Faculdade de Medicina, Universidade de São Paulo.

13. Urist, M. R., McLean, F. C.: Bone repair in rats with multiple fractures. Am. J. of Surgery 15: 685-695, 1950.

14. Wixson, S. K., White, W. J., Hughes, Jr, H. C., Lang, C. M., Marshall, W. K.: The effect of pentobarbital, fentanyl-droperidol, ketamine-xylazine and ketaminediazepam on core and surface body temperature regulation in adult male rats. Laboratory Animal Science 37: 743-749. 